\title{
Reevaluation of Land Fitness For Soybean Plant in Kabamatan Stabat, Langkat District
}

\author{
Leni Handayani ${ }^{1}$, A Rauf ${ }^{2}$, Rahmawaty ${ }^{3}$, T Supriana $^{4}$ \\ ${ }^{1}$ Department of of Agricultural Science, Universitas Sumatera Utara, Indonesia. \\ ${ }^{2}$ Department of Agriculture Agroecotechnology, Universitas Sumatera Utara, Indonesia. \\ ${ }^{3}$ Department of Agriculture forestry, Universitas Sumatera Utara, Indonesia. \\ ${ }^{4}$ Department Agriculture Agribusiness, Universitas Sumatera Utara, Indonesia.
}

\begin{abstract}
A decrease in the area of soybean farming has an effect on reducing soybean production from year to year so that it has not been able to meet the needs of national soybean consumption. Land suitability assessment is an effort to be able to optimize land use. In the process of assessing land suitability manually, it is considered inaccurate. The purpose of this study was to determine the land suitability class for soybean plants. The land suitability classification system used is the FAO land suitability classification classified at the sub-class level. Land suitability evaluation uses a matching system, as well as comparing the characteristics of land with plant growing community formulated in the technical evaluation of land guidelines for agricultural commodities. In the matching process Leibig's minimum law is used to determine the limiting factors that will affect the suitability of the class and sub-class of the land. Requirements for growing plants become criteria in conformity evaluation. The results showed that the limiting factors of land suitability for soybean plants that had to be adjusted were temperature, rainfall, soil texture, C-Organic, N-Total and PAvailable soil. The limiting factor of temperature and soil texture cannot be improved so that the marginal fit class (S3) on actual land suitability remains marginal fit (S3) in terms of potential land suitability.
\end{abstract}

\section{Article History}

Received 23 January 2020

Accepted 03 March 2020

Keywords

Farming,

Soybean,

Agricultural,

Land Suitability.

\section{Introduction}

In increasing crop productivity, the government is more focused on doing business related to increasing non-physical production such as expansion of crop areas, providing superior seeds and counseling on eradicating pests. Though plant production is not only influenced by non-physical conditions but also must pay attention to other physical conditions.

As food, soybean ranks number 3 after rice and corn as the main commodity of food crops in the food and feed industry in Indonesia (Isnowati, 2014). In Indonesia, the total area of soybean plantations has decreased by $41.6 \%$ over the last 20 years, namely from 1995 with a planting area of $1,476,284$ ha until 2015 , which only reached 614,095 ha of planted area (BPS, 2016). Of the 2015 land area, only 963,183 tons of soybeans were produced 
The amount of soybean production in 2015 has not been able to meet the needs of national soybean consumption which reached 2.87 million tons / year which will be predicted to continue to increase from year to year due to population growth (Global Agricultural Information Network, 2016). The still minimal use of land due to the decrease in soybean land area from year to year has an effect on the production of soybean produced. According to the research of Pilvere, et al.,(2014) states that inappropriate land use will have implications for low production which will have an impact on inefficient use of land resources. One effort to increase soybean agricultural production output is to allocate planting in suitable land (Widiatmaka, et al.,2016). Land use planning in the form of land suitability assessment is important to allocate soybean planting on suitable land to optimize land use (Dengiz, et al.,2013) and can also be used as a solution to increase production (Zhang, et al.,2015) soybeans to be sufficient national consumption needs. Land suitability assessments are important as a prerequisite for sustainable agriculture and play a role in planning for increasing agricultural productivity (Baniya, 2008; Neupane, et al.,2014). Besides aiming to increase agricultural productivity, assessing land suitability also takes into account the element of protection (FAO, 1993; Wali, et al.,2016). The intended protection is to protect existing natural resources from the dangers of damage such as avoiding land degradation or erosion due to the continuous land management process (FAO, 1976; Elaalem, etal.,2011).

Lack of understanding of land suitability will have an impact on environmental disturbances that have consequences on long-term problems that are difficult to change (Rodrigo, et al.,2004).

\section{Materials and Methods}

Materials and tools used during research are materials and tools commonly used for soil surveys and laboratory activities. The material used in the form of topographic maps, land maps, land use maps, administrative maps of Stabat District and other maps related to research. equipment used both in the field or in the Laboratory, namely soil drill to take soil samples and determine the effective depth of field in the field, abney level to determine the slope. GPS (Global Positinoning System) to determine the position of the study area and measure the altitude and a set of tools used for soil analysis in laboratories.

The study used a randomized block design (RBD) with 8 factorial $x$ and 4 factorial $y$. where the soil sample conditions will be seen namely temperature, water, oxygen content, root media, nutrient retention, nutrient availability, erosion, flooding, and land preparation. on land suitability of the 8 factorial $X$ will be given an assessment

$\mathrm{S} 1=$ very suitable

S2 = quite suitable

S3 = appropriate

and at the management level X2 namely: moderate, low, fertilizer and value acquisition.

In Factorial y there are 4 divisions namely:

1. actual land suitability

2. the heaviest limiting factor

3. Repair and Business

4. Potential land

with the following formula:

$$
\begin{array}{r}
Y i j=\mu+T i+B j+\varepsilon i j ; i=1,2,3 \ldots t \\
j=1,2,3 \ldots r
\end{array}
$$


$Y_{i j}=$ response or observation value from treatment $\mathrm{i}$ and repeat test $\mathrm{j}$

$\mu=$ general midpoint

$\mathrm{Ti}=$ the effect of the $\mathrm{i}$-th treatment

$\mathrm{Bj}=$ jth block's influence

$\varepsilon \mathrm{ij}=$ the effect of experimental error from the $\mathrm{i}$-th and $\mathrm{j}$-replication treatments

\section{Results and discussion}

Table 1. Soybean (Glycine max) land suitability assessment in Langkat Regency

\begin{tabular}{|c|c|c|c|c|c|c|c|}
\hline \multirow[t]{2}{*}{ Land Characteristic } & \multirow[t]{2}{*}{ Value } & \multirow{2}{*}{\multicolumn{2}{|c|}{$\begin{array}{l}\text { Actual Land } \\
\text { Suitability }\end{array}$}} & \multirow{2}{*}{$\begin{array}{c}\text { Heaviest } \\
\text { Limiting } \\
\text { factor }\end{array}$} & \multicolumn{2}{|c|}{$\begin{array}{c}\text { Repair } \\
\text { bussiness }\end{array}$} & \multirow{2}{*}{$\begin{array}{l}\text { Conformity of } \\
\text { Potential Land }\end{array}$} \\
\hline & & & & & Inp & & \\
\hline Temperature Regime (tc) & & & S2 & tc & & & S2 \\
\hline Average Temperature $\left({ }^{\circ} \mathrm{C}\right)$ & 25.8 & $\mathrm{~S} 2$ & & & & & \\
\hline Water Availability (wa) & & & S2 & Wa & & & S2 \\
\hline $\begin{array}{l}\text { Rainfall during Growth } \\
(\mathrm{mm})\end{array}$ & 1805 & $\mathrm{~S} 2$ & & & $\mathrm{D}$ & $\mathrm{S}$ & \\
\hline Average humidity $(\%)$ & 81 & $\mathrm{~S} 2$ & & & & & \\
\hline Oxygen Avaliability (oa) & & & S1 & & & & \\
\hline Drainage & Good & S1 & & & & & \\
\hline Rooting media (rc) & & & S3 & $\mathbf{R c}$ & & & S3 \\
\hline Soil Texture & Rather rough & S3 & & & & & \\
\hline Coarse material $(\%)$ & 29 & S2 & & & & & \\
\hline Land Depth $(\mathrm{cm})$ & 110 & S1 & & & & & \\
\hline Nutrition Retention (nr) & & & $\mathbf{S 3}$ & $\mathbf{N r}$ & & & S1 \\
\hline CEC Soil (me/100g) & $22.28(\mathrm{~S})$ & S1 & & & & & \\
\hline Base Saturation (\%) & 32.84 & $\mathrm{~S} 1$ & & & & & \\
\hline $\mathrm{pH} \mathrm{H}_{2} \mathrm{O}$ & 6.25 & S1 & & & & & \\
\hline C-organic (\%) & 0.61 & S3 & & & $\mathrm{O}$ & $\mathrm{S}$ & \\
\hline Avaliability of Hara (na) & & & $\mathbf{S 2}$ & $\mathbf{N a}$ & & & S1 \\
\hline $\mathrm{N}$-total $(\%)$ & $0.10(\mathrm{R})$ & S2 & & & $\mathrm{P}$ & $\mathrm{S}$ & \\
\hline $\mathrm{P}_{2} \mathrm{O}_{5}$ Bray II (ppm P) & $9.47(\mathrm{~S})$ & $\mathrm{S} 2$ & & & $\mathrm{P}$ & $\mathrm{S}$ & \\
\hline K-exchange (me/ $100 \mathrm{~g})$ & $0.625(\mathrm{~T})$ & S1 & & & & & \\
\hline Danger of Erotion(eh) & & & S1 & & & & \\
\hline Slope $(\%)$ & $<2$ & S1 & & & & & \\
\hline Danger of erotion & SR & S1 & & & & & \\
\hline Flood Hazard (fh) & & & S1 & & & & \\
\hline Flood Period & F0 & S1 & & & & & \\
\hline Land Preparation (lp) & & & S1 & & & & \\
\hline Surface Rock $(\%)$ & 0 & S1 & & & & & \\
\hline Rock outcrops & 0 & S1 & & & & & \\
\hline
\end{tabular}

\section{Land Suitability Value}

Keterangan : S1 = Very Appropriate S2 = Sufficiently appropriate

S3 = Marginal accordance
S3 rc 


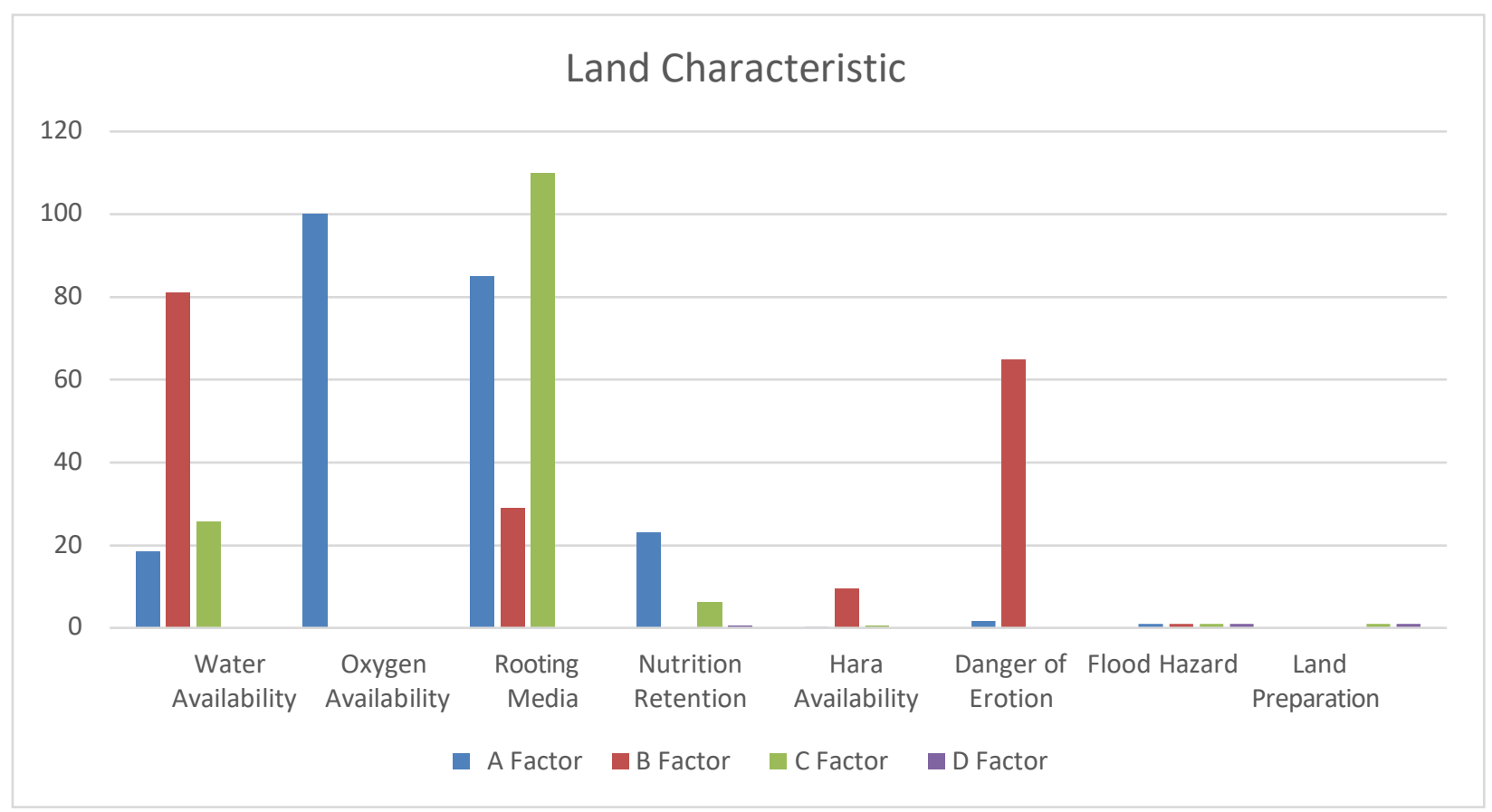

Figure 1. Land Characteristic of Langkat Regency

The limiting factors of land suitability for soybean plants that must be improved are temperature, rainfall, soil texture, C-Organic, $\mathrm{N}$-Total and P-Available soil. The limiting factor of temperature and soil texture cannot be improved so that the marginal fit class (S3) on actual land suitability remains marginal fit (S3) in terms of potential land suitability. This is in accordance with the statement of Mubekti (2012) which states the land limiting factors consist of two types, namely (1) permanent limiting factors in the sense that it is very difficult to repair if it will be opened for agricultural business, such limiting factors, such as temperature, soil texture, altitude, and (2) limiting factors that can be corrected, for example soil fertility, Al toxicity elements, soil acidity.

The limiting factor of high annual rainfall $(1805 \mathrm{~mm})$ can be done with the management of water systems with moderate to high level of management, namely by making drainage channels so that the class is quite suitable (S2) on the suitability of actual land to be very suitable (S1) in terms of potential land suitability.

The limiting factor of $\mathrm{N}$-total soil can be improved with a moderate level of management, namely by fertilizing according to plant needs. Estimated total $\mathrm{N}$ requirement of soybean plants for very suitable criteria requires $0.51 \%$ while the total $\mathrm{N}$ availability found in the soil at the time of the study was $0.10 \%$ so that an additional $0.40 \%$ is needed which is equivalent to $80 \mathrm{~kg} \mathrm{~N} /$ ha or $173.91 \mathrm{~kg}$ Urea / ha. The total fertilizer needed for soybean plants in the area requires an average increase of $25 \%$ to meet the needs of microbes and nutrient loss $\mathrm{N}$ so as to need the addition of fertilizer as much as $100 \mathrm{~kg} \mathrm{~N} / \mathrm{ha}$ or $217.39 \mathrm{~kg}$ Urea / ha. That way the suitability for total $\mathrm{N}$ becomes very suitable (S1) from the quite appropriate class (S2).

The P2O5 limiting factor of the soil can be improved with a low level of management that is by fertilizing according to plant requirements. The need for P2O5 soybean plants according to the criteria is very suitable, it requires $16 \mathrm{ppm}$ while the availability of P2O5 contained in the soil at the time of the research is $9.47 \mathrm{ppm}$ so that an additional $6.53 \mathrm{ppm}$ is 
needed which is equivalent to $130.6 \mathrm{~kg}$ P2O5 / ha equivalent to $362.77 \mathrm{~kg} \mathrm{SP36} \mathrm{/} \mathrm{Ha.} \mathrm{The} \mathrm{total}$ fertilizer needed for soybeans in the area required an additional $25 \%$ on average to meet microbial needs and phosphate loss so as to need the addition of fertilizer as much as $163.25 \mathrm{~kg}$ P2O5 / ha or $453.46 \mathrm{~kg} \mathrm{SP36} \mathrm{/} \mathrm{ha.} \mathrm{That} \mathrm{way} \mathrm{the} \mathrm{suitability} \mathrm{for} \mathrm{pospat} \mathrm{becomes} \mathrm{very} \mathrm{suitable} \mathrm{(S1)}$ of the class quite appropriate (S2).

The limiting factor of C-organic can be improved with a moderate level of management, namely by the addition of organic matter. Estimation of soybean C-organic requirement for very suitable criteria requires $3 \%$ while the availability of C-organic in the soil during research is $0.61 \%$ so an additional $2.39 \%$ is needed which is equivalent to 47.8 tons $C$ / ha or 82.4 tons of material organic / ha. However, the provision of organic material can be adjusted to the ability of farmers and the availability of organic material in the area. According to Akil et al (2015) the application of manure, or ashes of rice straw as a cover in the planting hole of 1-3 $t /$ ha is considered optimal. That way the land suitability class criteria for C-organic become very appropriate (S1) from the marginal appropriate class (S3).

\section{Conclusion}

The results of this study indicate that the adjustment of land suitability classes in the study area for soybean plants is included in the marginal suit class (S3), so that from the planting of soybean commodities it produces less than maximum production with rainfall limiting factors, nutrient retention. To improve the limiting factor for nutrient retention by adding organic material, the limiting factor for rainfall is quite high by making drainage channels.

\section{References}

Central Bureau of Statistics. 2016. Soybean Harvested Area by Province (ha), 1993-2015. Jakarta Baniya, Nabarath. 2008. LAND SUITABILITY EVALUATION USING GIS FO VEGETABLE CROPS IN

KATHMANDU VALLEY /NEPAL. Institute of Horticutural Scienc Faculty of Agriculture and Horticulture, Humboldt University zu Berlin, Berlin, Germany.

Dengiz, Orhan, Mehmet Arif O"zyazici, and Mustafa Sag lam. 2013. Multi-Criteria Assessment And Geostatistical Approach For Determination Of Rice Growing Suitability Sites In

Gokirmak Catchment. The International Society of Paddy and Water Environment Engineering and Springer Japan.

FAO, 1976. A framework for land evaluation. Soils Bulletin 32, Food and Agriculture Organization of the United Nations, Rome, Italy.

FAO, 1993. Guidelines for land-use planning. FAO development series 1, Vol.8 (96): Food and Agriculture Organization of the United Nations, Rome, Italy.

Global Agricultural Information Network. 2016. Indonesia Oilseeds and Products Annual Report 2016. GAIN Report: USDA Foreign Agricultural Service. Harseno, Edy dan Vickey Igor R Tampubolon. 2007. Application of Geographic Information Systems in Mapping Administrative, Land, Geological, Land Use, Slopes, Special Region of Yogyakarta and Watershed Areas in Central Java Using Arcview GIS Software. Scientific Magazine UKRIM Edisi 1/th XII/2007.

Isnowati, Sri. 2014. Factors Affecting Soybean Production in Kebonagung Village, Tegowanu District, Grobogan Regency. SEPA : Vol. 10 No.2 Februari 2014 : 177 - 185.

Pilvere I., A. Nipers, dan I. Upite. 2014. Agricultural Land Utilization Efficiency: The Case of Latvia. International Journal of Trade, Economics and Finance, Vol. 5, No. 1, February 2014. 
Sicat, Rodrigo. S, dkk. 2004. Fuzzy modeling of farmers' knowledge for land suitability classification. Agricultural Systems 83: 49-75.

Widiatmaka, Wiwin Ambarwulan, Yudi Setiawan,and Christian Walter. 2016. Assessing the Suitability and Availability of Land for Agriculture in Tuban Regency, East Java, Indonesia. Applied and Environmental Soil Science Volume 2016, Article ID 7302148, 13 pages.

Zhang, Jiuquan, Yirong Su, Jinshui Wu, and Hongbo Liang. 2015. GIS based land suitability assessment for tobacco production using AHP and fuzzy set in Shandong province of China. Computers and Electronics in Agriculture 114 